\title{
The Impact of Religion on Gender Gap in Adult Literacy in Developing Countries
}

\author{
Fangyao Liu \\ College of Information Science \& Technology, University of Nebraska at Omaha, USA. \\ 1110 S 67 th St, Omaha, NE 68182, USA \\ E-mail: fangyaoliu@unomaha.edu \\ Xixi Feng \\ College of Business Administration, University of Nebraska at Omaha, USA \\ 6708 Pine St, Omaha, NE 68106, USA \\ E-mail: 359400016@qq.com
}

Received: December 29, 2018 Accepted: January 28, 2019 Published: February 20, 2019

doi:10.5296/jad.v5i2.14069 URL: https://doi.org/10.5296/jad.v5i2.14069

\begin{abstract}
Literacy measures human capital of a country, literacy rates are much lower in developing countries compared to developed countries, especially the gap in literacy rates between men and female. We examine the determinants of the gender gap in literacy rates in developing countries, particularly the relationship between religion and gender gap in literacy. From the empirical study, we show that Protestant and Islam increase the gender gap in literacy in developing countries controlling other factors.
\end{abstract}

Keywords: Adult literacy, religion, gender, developing country, regression model

\section{Introduction}

With the development of the economy, education and human capital have been considered as important factors of a country's development. Literacy has also been assessed to measure a country's human capital. Literacy is a significant indicator of a country's economic development, the economic growth and industrialization triggering the demand for the educated and skilled labor force, which increase the literacy rate (Verner, 2005). Furthermore, literacy can promote productivity, as literate workers can acquire skills faster than illiterate 
workers.

The importance of literacy is quite accepted. Verner (2005) mentioned that literacy is a significant indicator of a country's economic development, with the increase of economic growth and industrialization, it triggered the demand for the educated and skilled labor force, which increased the literacy. Furthermore, Verner (2005) also talked about that literacy can promote the productivity, as the literate workers can acquire skills quickly than illiterate workers. However, literacy is very low in developing countries, especially female literacy. The gender gap in adult literacy in India is 22 percentage point in 1998 (Borooah \& Iyer, 2002). Female low literacy in developing countries is a hot issue that calls much attention. Investing in female education can not only improve a country's economic growth, as more educated female workers are participating in the labor force but also an indicator for human capital, especially for the next generation (Cooray \& Potrafke, 2011). Norton and Tomal (2009) also stressed the importance of female education, stating that educating in a female would have some lagged effects on economic growth since they can take care of their kids and educate them better than illiterate moms, which would have a positive effect on children's generation.

However, although illiteracy has almost disappeared in developed countries, the number of illiterate people in developing countries is still huge, especially among women. In India, only $65 \%$ of the total adult population is literate in 2001 , and only $54 \%$ of women were literate, while $76 \%$ of men were literate, and the gap has lasted for about forty years (Sundaram \& Vanneman, 2007). Low female literacy in developing countries is a concern that needs our attention. Investing in female literacy not only improves a country's economic growth, as more educated female workers are participating in the labor force, it builds human capital of a country, especially for the next generation (Cooray \& Potrafke, 2011). Norton and Tomal (2009) stressed the importance of female education, stating that educating in the female has potentially positive lagged effects on economic growth because literate moms can take care of their kids and educate them better than illiterate moms, which has a positive effect on children's generation.

Female literacy is also different among countries. Halder (2012) showed that the female literacy in India is way much slower than some of the developing countries in South-East Asia after 1960's: Maldives, Thailand, China, Singapore are 80-90 percent, but in India, it is less than 50 percent. They all have similar economic background and region, even India is standing out in economic growth than other countries, the difference is that India is dominated by Muslim and Hindu religion, other countries are not Islam dominated. Considering the importance of literacy, especially female literacy for a country, it is worthwhile to find the determinants of the gender gap in adult literacy in developing countries, thus these countries can improve female literacy rate and minimize the gender gap in literacy rate and increase human capital.

\section{Literature Review}

There are some literature discussing the relationship between religion and education or literacy. Becker and Woessmann (2010) found that Protestantism promotes the number of 
schools and school enrolment ratio before the industrialization, which later on led to the industrialization. Chaudhary and Rubin (2011) used data in India to show that literacy is negatively related to the proportion of Islam adherents in the district. Okpala and Okpala (2009) examined the data of 34 Sub-Saharan countries, they showed that countries with larger Islam believers have lower adult and female literacy rates, compared to countries with larger Christianity believers, the reason is that the early church missionary movement promoted the establishment of schools, countries that benefited from the early Christian mission schools experienced higher literacy rate than other countries. Furthermore, many kinds of literature focused on religion and female education. Norton and Tomal (2009) stated the relationship between female education, religion, and economic growth, they stated that religion is the reflection of social norm, it can affect education of a society, which in turn promote or retard a country's economic growth. To testify their hypotheses, Norton and Tomal (2009) used data of 97countries to do empirical study. They presented a regression model to analyze the effect of religion on female education attainment and gender gap in education attainment, they measure religion as the proportion of population that is Buddhist, ethno-religion, Hindu, Muslim, Orthodox, Protestant or Roman Catholic, and found that Orthodox, Hindu, and Muslim inhibit female education and gender gap in education. Based on their work, Cooray and Potrafke (2011) discussed whether political institution and religion affect gender gap in education. They stated that in Nietzschean society, women are victims of male domination, for example, the discrimination of female education and traded for women, because women are physically weak. Different from Norton and Tomal (2009), Cooray and Potrafke (2011) measured religion with dummy variables which take on the value of one when a specific religion is dominated in a country, their base category of religion variable is Christianity, they explained that the British introduced Christianity to the African and Asian colonies, thus most of these countries are primarily Christianity, while Norton and Tomal (2009) assumed that Protestantism promotes female education while other religions inhibit it. From the empirical study, Cooray and Potrafke's (2011) showed that countries dominated by indigenous religion and Muslim religion have higher gender inequality.

Borooah and Iyer (2002) observed that religion and caste do affect education, and further explained the reason that why religion effect gender gap in education in India. They pointed out that the decision to send a child to school could be a cost-benefit decision. While a son is supposed to support the family, a girl's goal is marriage, parents would think it's not worthwhile to send a girl to school. The "preference for son" culture in India also result in the discrimination in female education. Borooah and Iyer (2002) used the data from a survey of 33,000 rural families, in 1,765 villages, from 16 states of India, distinguished caste and religious variables by Hindus, Muslims, and Christianity, they found that school enrollments were highest for Hindus, then Muslims, last were Dalits. They stressed that the Muslim norms of women may lead to the low level of female education, in Muslim society, it is thought that educated women may be disloyal to their family because she can contact other men with writing. They also afraid that girls with education may violate the practice of purdah. In addition, Dalits are the lowest caste in India, they are discriminated in the society including school, hence the Dalits are less likely to send kids to school. Other than India, Africa is also stand out for its low female literacy. According to Verner (2005), more than 90 
percent of women are illiterate in Niger and Burkina Faso. The spread of Western culture to Sub-Saharan Africa may cause the differences in literacy rates in these countries. There are also other factors contribute to the gender gap in literacy other than religion. Mazumdar (2005) stressed that government expenditure on education is a country's commitment to education, in this way government expenditure on education decrease the gender gap in literacy; Okpala and Okpala (2009) proved that urbanization promotes human capital, investing in human capital would have greater returns in urban areas, so higher urbanization level increase the literacy rate; Norton and Tomal (2009) discuss the effect of participation of women in labor force on female education, and found that female labor participation depress female higher education, because the substitution effect of labor for education; Verner (2005) used data from 180 countries coming from the World Bank to analyze the determinants of literacy. He presented a regression model to analyze the factors behind literacy and found out that formal education significantly affects literacy rates, both the increase in school enrollment rates and average years of schooling of adults are related to the increase of literacy rate; higher life expectancy result in higher literacy rates, as health is the guarantee of people to read and write.

Most of the literatures studied female education, rarely did they discuss the determinants of the gender gap in literacy. There are some differences between literacy and education, literacy is the basic skill of reading and writing, while education is to apply these skills to the society. Most of the developed countries have already achieved 100\% literate over the society, but many people in developing countries are still struggling to be literate, let alone the huge gender gap in literacy. It would be more important to explore the literacy rather than education in developing countries. Besides, the gap in literacy between men and women in developing countries is very huge. The male literacy rate is $56.5 \%$ while female literacy rate is $32.6 \%$ in Pakistan according to Ambreen and Mohyuddin (2012). Although some literature has shown the effect of religion on education, we want to test if it shows the same result on gender gap in literacy. Based on related literatures, we examine the relationship between religion and gender gap in adult literacy in developing countries controlling other factors. We put religion into four categories: Protestant, Catholic, Islam, and others, because these are the most popular religions in the developing countries. Through the empirical study, we find that countries dominated by Islam, i.e. countries that have more Islam adherents, their gender gap in adult literacy is higher than countries dominated by Protestant, Catholic, and other religions.

We structure the rest of the paper as follows. We discuss the model in the next section, then we talk about the data and empirical results and make the conclusion.

\section{The Model}

We construct a cross section data to do the empirical study. Our model comes from Norton and Tomal (2009), they used a linear model to generate the determinants of the gender gap in education attainment. Based on the literature, we estimate that:

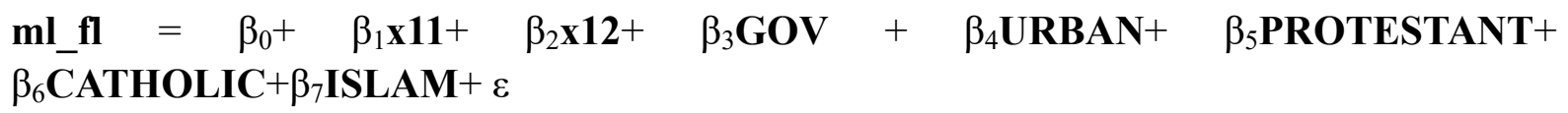


We use the ratio of male adult literacy rate divided by female literacy rate to measure the gender gap of literacy rate, which is our dependent variable ML-FL, the higher the ratio, the bigger the gender gap in literacy rate. The religion variables, which are our main variables. We divide religions into four categories: Protestant, Catholic, Islam, and Others. We measure religions as the proportion of the population in a country. Norton and Tomal (2009) stated that literacy rates are promoted through Bible reading in Protestantism, Protestant enhance female education, so, we expect that more Protestant adherents of a country could contribute to the lower gender gap in literacy rate. While in Catholic countries, they have authoritarian government and religion, they disdain work ethic and have less public spirit. Norton and Tomal (2009) showed that Catholic lowers female secondary education attainment, but they do not find evidence that Catholics contribute to the gender gap in education. We expect the impact of Catholic on the gender gap in literacy is ambiguous. As for Islam, we expect that Islam would inhibit female literacy, hence countries with more Islam believers lead to the larger gender gap in literacy rate. Cooray and Potrafke's (2011) showed that Muslim countries are known for more authoritarian and less democratic, countries dominated by Islam religion have higher gender inequality. Our control variables: GDP per capita (GDP), public expenditure on education (GOV), and URBAN measures the percentage of the population that live in urban areas. Verner (2005) explored that economic growth has a significant impact on literacy, so we expect gender gap would be minimized with the increase of GDP per capita. We divide GDP variable into three groups: higher income, median income, and lower income, and denoted them by 1, 0 and -1 . Here, we use the Z-score transform method. which means, for each GDP observation, we transform it to a Z-score, this is also called the standardizations. The standard $\mathrm{Z}$ score formula is:

$$
\mathrm{Z}=\frac{X-\mu}{\sigma}
$$

where:

$\mu$ is the mean of the population.

$\sigma$ is the standard deviation of the population.

The first step is to calculate the average value, then calculate the standard deviation. For each GDP observation, will assign a standardized Z-score.

Based on the Z-score, we define the GDP category as the following rules:

A. If the $\mathrm{Z}$ score $>1$, then assign it to high category, which denote as 1 .

B. if the $\mathrm{Z}$ score $<-1$, then assign it to low category, which denote as -1 .

C. the $\mathrm{Z}$ score $>=-1$, and $\mathrm{Z}$ score $<=1$, then assign it to high category, which denote as 0 .

In addition, we use two dummy variables to define GDP: x11 and x12. We define that:

A. If $\mathrm{GDP}=1$, it is high income country, then $\mathrm{x} 11=1$, $\mathrm{x} 12=0$;

B. If GDP $=-1$, it is low income country, then $\mathrm{x} 11=0, \mathrm{x} 12=1$; 
C. If $\mathrm{GDP}=0$, it is middle income country, then $\mathrm{x} 11=0, \mathrm{x} 12=0$.

We can express it as a matrix Table 1.

Table 1. GDP matrix

\begin{tabular}{llll}
\hline & Z-Score & X11 & X12 \\
\hline High GDP & 1 & 1 & 0 \\
Low GDP & -1 & 0 & 1 \\
Middle GDP & 0 & 0 & 0 \\
\hline
\end{tabular}

Based on the matrix table 1 above, it is easy to conclude that all the value for the dummy variable could be either 1 or 0 , which is just a binary variable. one of the reasons to use dummy variable rather than a continuous variable is due to the independent assumption, one of the assumption for independent variable is the normality, if the independent is category variable, it is not appropriate to talk about the normality or not, so, we should use the dummy variable here. Further, the model could be easily explained for the really meaning, rather than the statistical meaning. Adopting the dummy variable could be easily for model difference based on different situation. For example, the literate gap here possibly has different model based on different GDP group. What's more, use the dummy variable associate with the test for significant, could contribute to the dummy group segment validation. The methodology is if and only if all the test for the dummy variable test showed the significant, we can say this dummy variable segment is great and make sense, otherwise, the segment should be re-do, which means we should divide the group based on other criteria. Such as if we divided the groups into Category-A, Category-B, Category-C, Category- $\mathrm{D}$, based on the significant test, one dummy variable is not significant, then we can try to divide the group into Category-X, Category-Y, Category-Z.

Public expenditure on education (GOV) is measured by the percentage of GDP per capita, it shows a country's commitment to education (Mazumdar, 2005), which promotes the growth of literacy, so we assume that the more of the government expenditure, the smaller gender gap; URBAN measures the percentage of the population that live in urban areas, Okpala and Okpala (2009) proved that urban population have a significant positive impact on literacy, because urbanization promotes human capital, we expect that the higher the urban population percentage, the lower the gender gap in literacy. Data used in the estimation model is summarized in Appendix 1.

Table 2 is the descriptive statistics for all the variables. It reveals some striking results. We use the ratio of male-and-female literacy rates to measure the gender gap in adult literacy, a ratio of 1 shows parity between male and female in literacy rates, and the ratio higher than 1 indicates that male literacy rates are higher than female literacy. The mean number of $\mathrm{ml}$ - $\mathrm{fl}$ is 1.31 , showing that on average, male literacy rates are higher than female literacy rates in these countries. Guinea has the largest gender gap in literacy rates, which is 2.70 , while in 


\section{Macrothink}

Lesotho, the ratio is 0.86 , which implies that the female literacy rates are higher than male literacy in Lesotho. The minimum number of gov comes from Sudan, which means that Sudan only spent $1.01 \%$ of GDP per capita in spending on education. In Burundi, only $8.25 \%$ of the total population lives in urban areas, while in Nauru, the whole population of the country lives in urban areas. As for religion variables, the proportion of Protestant adherents is smaller than that of Catholic and Islam, the same is the sum number. Tuvalu has the largest Protestant adherents, Mexico is dominated by Catholic, with $93.82 \%$ of people are Catholic adherents, and most of the Middle-East countries are dominated by Islam.

Table 2. Descriptive Statistics

\begin{tabular}{llllll}
\hline Variable & Mean & Median & Maximum & Minimum & Std.Dev \\
\hline ML-FL & 1.3063 & 1.1619 & 2.6955 & 0.8627 & 0.3852 \\
GDP & -0.3206 & 0 & 1 & -1 & 0.6594 \\
GOV & 4.3572 & 4.3326 & 11.1858 & 1.0121 & 1.7153 \\
URBAN & 44.4282 & 42.958 & 100 & 8.246 & 19.9523 \\
PROTESTANT & 12.7595 & 5 & 94 & 0 & 18.3241 \\
CATHOLIC & 25.5629 & 10.37 & 93.82 & 0 & 30.4857 \\
ISLAM & 29.9716 & 6.65 & 100 & 0 & 38.3368 \\
OTHERS & 31.7058 & 22.66 & 100 & 0 & 30.6078 \\
\hline
\end{tabular}

Table 3 shows correlation coefficients of the variables in the model. All of them are all statistically significant and show the same correlation as we expected. The results imply that GDP, GOV, URBAN, PROTESTANT, CATHOLIC and other religions are all negatively related to the ratio of male-to-female literacy rates, meaning that the higher the GDP, the lower the gender gap in literacy; the higher the GOV, the lower the gender gap in literacy ; the higher the URBAN, the lower the literacy gap; the more population of PROTESTANT, the lower the literacy gap; the more population of CATHOLIC, the lower the literacy gap; only ISLAM is positively related to the gender gap, the more Islam adherents, the larger the gender gap. 


\section{Macrothink}

Table 3. Correlation Coefficients.

\begin{tabular}{lllllllll}
\hline Variable & GDP & GOV & URBAN & PROTESTANT & CATHOLIC & ISLAM & OTHERS & ML-FL \\
\hline GDP & 1.000000 & & & & & & & \\
GOV & 0.188309 & 1.00000 & & & & & & \\
URBAN & 0.5574 & 0.05355 & 1.000000 & & & & & \\
PROTESTANT & 0.189712 & 0.22337 & -0.07766 & 1.000000 & & & \\
CATHOLIC & 0.358278 & 0.02968 & 0.251666 & 0.095571 & 1.000000 & & \\
ISLAM & -0.16981 & -0.09029 & -0.03240 & -0.449048 & -0.544996 & 1.00000 & & \\
OTHERS & -0.25774 & -0.05019 & -0.16358 & -0.131424 & -0.370612 & -0.4408 & 1.000 & \\
ML-FL & -0.29243 & -0.24173 & -0.29941 & -0.048292 & -0.208232 & 0.25815 & -0.087 & 1.000 \\
\hline
\end{tabular}

\section{The Empirical Results}

We collect data which come from the World Bank and Association of Religion Data Archives website and contains up to 131 countries. We exclude the "high income" countries indicated by the World Bank to generate our developing countries.

We first run the regression in EVIEWS, table 4 shows the result of the regression. the adjusted R-squared is 0.1858 , which means the model is not fit very well. $\mathrm{x} 11$ is not significant; GOV is statistically significant, showing that the more the government expenditure on education, the lower the gender gap in literacy; URBAN is statistically significant, meaning that the more urban population of a country, the lower gender gap in literacy. As for religion variables, PROTESTANT is statistically significant, the positive sign showing that the more population of Protestant, the larger gender gap in literacy, which is contradict to our previous expectation; Catholic is not statistically significant, meaning that we do not find evidence that Catholic is contributed to the gender gap in literacy; ISLAM is statistically significant, meaning that the more population of Islam, the larger the gender gap in literacy. 
Table 4. Regression Results

\begin{tabular}{|c|c|}
\hline Variables & OLS \\
\hline \multirow[t]{2}{*}{$\mathrm{X} 11$} & 0.0711 \\
\hline & $(0.1053)$ \\
\hline \multirow[t]{2}{*}{$\mathrm{X} 12$} & $0.1598 * *$ \\
\hline & $(0.0779)$ \\
\hline \multirow[t]{2}{*}{ GOV } & $-0.0444 * *$ \\
\hline & $(0.0186)$ \\
\hline \multirow[t]{2}{*}{ URBAN } & $-0.0038^{*}$ \\
\hline & $(0.0019)$ \\
\hline \multirow[t]{2}{*}{ PROTESTANT } & 0.0030 \\
\hline & $(0.0020)$ \\
\hline \multirow[t]{2}{*}{ CATHOLIC } & 0.0005 \\
\hline & $(0.0013)$ \\
\hline \multirow[t]{2}{*}{ ISLAM } & $0.0028 * * *$ \\
\hline & $(0.0010)$ \\
\hline R-squared & 0.2297 \\
\hline AdjustedR-squared & 0.1858 \\
\hline F-statistic & $5.2396 * * *$ \\
\hline $\mathrm{n}$ & 131 \\
\hline
\end{tabular}

Note. Dependent Variable: Ratio of male literacy divided by female literacy

$* * *, * *, *$ indicate significantly different from zero at the $1 \%, 5 \%, 10 \%$ level.

According to the previous results, we exclude the x11 and CATHOLIC variable, and do some transformation for the model:

ml_fl $=\beta_{0}+\beta_{1} \mathbf{x 1 2}+\beta_{2}$ GOV $+\beta_{3}$ URBAN $+\beta_{4}$ LOGPROTESTANT $+\beta_{5}$ ISLAM $+\varepsilon$

Because PROTESTANT is not normal distribution, we do the log transformation for PROTESTANT, after the log function transformation, we did another normality test for LOGPROTESTANT, the test result passed the normality test which means that the new variable meets the normality assumption.

Table 5 illustrates our revised regression results. The adjusted R-squared increased from 0.1858 to 0.3164 , which means that our new model fits better, the F-statistic is also significant. All the variable other than URBAN is significant. 


\section{NI Macrothink}

Table 5. Revised Regression Results.

\begin{tabular}{ll}
\hline Variables & OLS \\
\hline X12 & $0.1603^{* *}$ \\
& $(0.0770)$ \\
\hline GOV & $-0.0395^{* *}$ \\
& $(0.0192)$ \\
\hline URBAN & -0.0029 \\
& $(0.0018)$ \\
\hline LOGPROTESTANT & $0.0610^{* * *}$ \\
& $(0.0193)$ \\
\hline ISLAM & $0.0058^{* * *}$ \\
& $(0.0013)$ \\
\hline R-squared & 0.3470 \\
FdjustedR-squared & 0.3165 \\
$\mathrm{n}$ & $11.3706^{* * *}$ \\
\hline
\end{tabular}

Note. Dependent Variable: Ratio of male literacy divided by female literacy.

$* * *, * *, *$ indicate significantly different from zero at the $1 \%, 5 \%, 10 \%$ level.

Next, we did the White test to see if there is Heteroscedasticity. The results of White test are shown in table 6. The F-statistic is $2.3383, \mathrm{P}$ value is 0.0038 , which means there is heteroscedasticity. Heteroscedasticity means that the error term variance is not constant, it obeys the assumption of homoscedasticity, which means that the Gauss-Markov theorem is not satisfied. The OLS estimators are not the Best Linear Unbiased Estimators, and their variance is not the lowest of all the unbiased estimators.

Heteroscedasticity often rise in cross section data, in our data, it may be that the error term is correlated with the independent variables, so the variance of error term is changing with the independent variables. 
Table 6. Heteroskedasticity Test: White.

\begin{tabular}{llll}
\hline F-statistic & 2.338320 & Prob. F(19,93) & 0.0038 \\
Obs*R-squared & 36.53091 & Prob. Chi-Square(19) & 0.0091 \\
Scaled explained SS & 52.46359 & Prob. Chi-Square(19) & 0.0001 \\
\hline
\end{tabular}

\section{Test Equation:}

Dependent Variable: RESID $²$

Method: Least Squares

Date: 04/23/18 Time: 22:33

Sample: 1131

Included observations: 113

Collinear test regressors dropped from specification

\begin{tabular}{lllcl} 
Variable & Coefficient & Std. Error & t-Statistic & Prob. \\
\hline C & -0.615602 & 0.316870 & -1.942756 & 0.0551 \\
X12 & 0.492018 & 0.228378 & 2.154398 & 0.0338 \\
X12*GOV & -0.025400 & 0.031481 & -0.806831 & 0.4218 \\
X12*URBAN & -0.004879 & 0.003011 & -1.620543 & 0.1085 \\
X12*LOGPROTESTANT & -0.081452 & 0.028509 & -2.857078 & 0.0053 \\
X12*ISLAM & -0.004835 & 0.001733 & -2.789163 & 0.0064 \\
GOV & 0.096923 & 0.063241 & 1.532608 & 0.1288 \\
GOV^2 & -0.000539 & 0.003438 & -0.156755 & 0.8758 \\
GOV*URBAN & -0.001252 & 0.000786 & -1.592465 & 0.1147 \\
GOV*LOGPROTESTANT & -0.013730 & 0.009676 & -1.418963 & 0.1593 \\
GOV*ISLAM & 0.000455 & 0.000513 & 0.888536 & 0.3765 \\
URBAN & 0.010923 & 0.006445 & 1.694694 & 0.0935 \\
URBAN^2 & $-4.03 \mathrm{E}-05$ & $4.41 \mathrm{E}-05$ & -0.913415 & 0.3634 \\
URBAN*LOGPROTESTANT & -0.000206 & 0.000636 & -0.323285 & 0.7472 \\
URBAN*ISLAM & $-6.24 \mathrm{E}-05$ & $4.56 \mathrm{E}-05$ & -1.369955 & 0.1740 \\
LOGPROTESTANT & 0.070979 & 0.056507 & 1.256106 & 0.2122 \\
LOGPROTESTANT^2 & 0.012087 & 0.005297 & 2.281910 & 0.0248 \\
LOGPROTESTANT*ISLAM & 0.001748 & 0.000487 & 3.585612 & 0.0005 \\
ISLAM & 0.001746 & 0.004530 & 0.385568 & 0.7007 \\
ISLAM^2 & $6.10 \mathrm{E}-05$ & $3.37 \mathrm{E}-05$ & 1.813570 & 0.0730 \\
\hline R-squared & 0.323282 & \multicolumn{2}{c}{ Mean dependent var } & 0.105236 \\
Adjusted R-squared & 0.185028 & \multicolumn{2}{c}{ S.D. dependent var } & 0.189192 \\
S.E. of regression & 0.170795 & \multicolumn{2}{c}{ Akaike info criterion } & -0.537516 \\
Sum squared resid & 2.712886 & \multicolumn{2}{c}{ Schwarz criterion } & -0.054792 \\
Log likelihood & 50.36963 & Hannan-Quinn criter. & -0.341631 \\
F-statistic & 2.338320 & Durbin-Watson stat & 2.285444 \\
Prob(F-statistic) & 0.003838 & & & \\
\hline & & & &
\end{tabular}

In order to eliminate the influence of heteroscedasticity, we use the White method to correct 
it.

In the White correction, we replace the unknown variance by the residual of observation to the square:

$$
\operatorname{Var}(\hat{\beta} 1)=\sum(X i-\bar{X})^{2} U i^{2} /\left[\sum(X i-\bar{X})^{2}\right]^{2}
$$

The revised regression results are shown in table 7 . The adjusted-R square is 0.3165 , which is good for the model fit, the F-statistic is 11.3706 , which is statistically significant. $\mathrm{x} 12$ is statistically significant, it shows that for developing countries with lower income, $16 \%$ of them with higher GDP per capita, the gender gap is lower, which is consistent with the results Cooray and Potrafke (2011), and our base countries are the middle and higher income in developing countries. GOV is statistically significant, it means that for one unit increase of government expenditure on education, the gender gap in literacy will decrease by 0.0395 unit, which is consistent to the literature. Mazumdar (2005) shows that government expenditure on education is a country's commitment to education, which promotes the growth of literacy, so we assume that the more of the government expenditure, the smaller gender gap. URBAN is statistically significant, meaning that for one unit increase of urban population, the gender gap in literacy will decrease by 0.0028 unit. It is also the same as we expected, Okpala and Okpala (2009) proved that urban population have a significant positive impact on literacy, because urbanization promotes human capital, we expect that the higher the urban population percentage, the lower the gender gap in literacy. As for religion variables, since we exclude CATHOLIC, we only consider LOGPROTESTANT and ISLAM. The LOGPROTESTANT is statistically significant, showing that when the population of protestant adherents of a country increase by one unit, the gender gap in literacy increase by 0.0610 unit, which is contradict with the literature. Norton and Tomal (2009), Becker and Woessmann (2010) found that Protestant decrease the gender gap in education, we get the different result may ay due to the fact that our data all come from developing countries, their proportion of Protestant adherents is very small, while most of the literature investigate the protestant adherent over the world, and the proportion of Protestants are very large in the developed countries. ISLAM is statistically significant, meaning that when a country's adherents of Islam increase by one unit, the gender gap in literacy will increase by 0.0016 unit, which is consistent with the finding of Norton and Tomal (2009), Cooray and Potrafke (2011), Borooah and Iyer (2002), Islam do increase gender gap in literacy.

The test of Significant is really valuable and necessary. After the model is built, we should test the model's significant, which means the model is robust or not. There are two test we have to do, one is the F-test, which is used to test the model, the other one is T-test. More details will be explained later, basically, the F-test is telling us that the overall model make a difference, and the T-test is used to show us that each independent variable will make a difference. So, it makes a lot of sense for us to do the F-test first, if F-test passed, then continue to T-test stage. The T-test should be used to judge each independent variable's significant, so, the number is the T-test should be the same as how many independent 
variables the model has.

The F-test is about to test the overall model, so the Null hypothesis and Alternate hypothesis are as follows:

$\mathrm{H} 0: \quad \beta 1=\beta 2=\beta 3=\beta 4 \ldots \ldots=\beta \mathrm{k}=0$

H1: Not all of them are equal.

This is basically a means equality test for more than two population, so the ANOVA table will be the best tools, the ANOVA table is an analysis of variance, which is used the idea about the variance of between group and the variance between group. The test static is the F-value, or we can say it is F-test. After we get the F-value, there are two approaches to deal it with, the first is called critical approach, which is use the F-value to compare with critical F-value, if the F-value is larger than the critical value, then we should reject the Null hypothesis, otherwise, fail to reject it. another one is the P-value approach, based on the F-value, we can get a responding P-value, then compare it with significant level $\alpha$, which as usually equal to 0.05 , if the p-value is smaller than $\alpha$, then we can reject it, otherwise, we could not reject the original hypothesis.

The T-test is used very common for means equality test for two populations. T-test for variable, is the test about the variable coefficient equal to zero or not. so the Null hypothesis and Alternate hypothesis are as follows:

$\mathrm{H} 0: \quad \beta \mathrm{i}=0$

H1: $\quad \beta i$ not equal to zero.

The test static for this T-test equal to $\left(b_{\mathrm{i}}-0\right) / \mathrm{SE}$-coff. There are two approaches too here. It is very similar to the F-test, Critical value approach and P-value approach. No matter which approach, if the reject the Null hypothesis, then we should reject the H0, and reach the conclusion that the coefficient for this independent variable is significant. Totally, we should do all the T-test for each independent variable to make sure all of them are meet the significant requirement. 
Table 7. Revised Regression Results After White method.

\begin{tabular}{ll}
\hline Variables & White \\
\hline X12 & $0.1603^{* *}$ \\
& $(0.0787)$ \\
\hline GOV & $-0.0395^{* *}$ \\
& $(0.0167)$ \\
\hline URBAN & $-0.0029^{*}$ \\
& $(0.0016)$ \\
\hline LOGPROTESTANT & $0.0610^{* * *}$ \\
& $(0.0207)$ \\
\hline ISLAM & $0.0059^{* * *}$ \\
& $(0.0016)$ \\
\hline R-squared & 0.3470 \\
AdjustedR-squared & 0.3165 \\
F-statistic & $11.3706^{* * *}$ \\
$\mathrm{n}$ & 131 \\
\hline Note. Dependent Variable: Ratio of male literacy divided by female literacy. \\
$* * *, * *, *$ indicate significantly different from zero at the $1 \%, 5 \%, 10 \%$ level.
\end{tabular}

\section{Summary and Conclusion}

In this paper, we use cross section data to discuss the relationship between religion and gender gap in literacy rates in developing countries. Our empirical results show that religion do contribute to the gap in literacy rates between men and women. When controlling other factors, Islam and Protestant increases gender gap in literacy rates. We do not find support for the relation between Catholic and gender gap in literacy. Recognize the interaction between religion and literacy is important, because policy makers need to take religion factor into consideration when they make decisions. For Muslim countries, the normal policy may not be effective, they need to conduct policy that fits their own situation. Due to the missing data, some of our results may be biased. We will improve the data quality and accuracy in the future.

This research is meaningful for both academic research and policy makers, because it does uncover some hidden findings, which give a support for further analysis and discussion.

\section{References}

Becker, S. O., \& Woessmann, L. (2010). The effect of Protestantism on education before the industrialization: Evidence from 1816 Prussia. Economics Letters, 107(2), 224-228. https://doi.org/10.1016/j.econlet.2010.01.031

Borooah, V. K., \& Iyer, S. (2005). Vidya, Veda, and Varna: The influence of religion and caste on education in rural India. The Journal of Development Studies, 41(8), 1369-1404. https://doi.org/10.1080/00220380500186960 
Chaudhary, L., \& Rubin, J. (2011). Reading, writing, and religion: Institutions and human capital formation. Journal of Comparative Economics, 39(1), 17-33. https://doi.org/10.1016/j.jce.2010.06.001

Cooray, A., \& Potrafke, N. (2011). Gender inequality in education: Political institutions or culture and religion?. European Journal of Political Economy, 27(2), 268-280. https://doi.org/10.1016/j.ejpoleco.2010.08.004

Halder, S. (2012). Literacy Progression of Women in Developing Countries of South-East Asia with Special Reference to West Bengal, India. Asia Pacific Journal of Social Sciences, 4(2), 88-107.

Mazumdar, K. (2005). Socio-economic factors determining adult literacy in developing countries. International Journal of Social Economics, 32(1/2), 98-120. https://doi.org/10.1108/03068290510575667

Norton, S. W., \& Tomal, A. (2009). Religion and female educational attainment. Journal of Money, Credit and Banking, 41(5), 961-986. https://doi.org/10.1111/j.1538-4616.2009.00240.x

Okpala, A., \& Okpala, C. (2009). Economics \& religious implications on adult literacy in sub-Saharan Africa. The Journal of Applied Business Research, 25(1), 83-90.

Sundaram, A., \& Vanneman, R. (2008). Gender differentials in literacy in India: The intriguing relationship with women's labor force participation. World Development, 36(1), 128-143. https://doi.org/10.1016/j.worlddev.2007.02.017

Verner, D. (2005). What factors influence world literacy? is Africa different?. The World Bank. https://doi.org/10.1596/1813-9450-3496 
Appendix

Appendix 1. Summary Table of Data

\begin{tabular}{|c|c|c|c|c|c|}
\hline Variable & Definition & $\begin{array}{l}\text { Data } \\
\text { Source }\end{array}$ & $\begin{array}{c}\text { Unit of } \\
\text { Analysis }\end{array}$ & $\begin{array}{l}\text { Level } \\
\text { Analysis }\end{array}$ & $\begin{array}{l}\text { Hypothesized } \\
\text { Impact }\end{array}$ \\
\hline ML-FL & $\begin{array}{l}\text { adult male literacy } \\
\text { rate divided by adult } \\
\text { female literacy rate of } \\
\text { the developing } \\
\text { countries in } 2000\end{array}$ & $\begin{array}{l}\text { The } \\
\text { World } \\
\text { bank }\end{array}$ & percentage & $\begin{array}{l}\text { Collected } \mathrm{f} \\
\text { each } \\
\text { developing } \\
\text { country } \mathrm{f} \\
\text { year 2000 }\end{array}$ & N/A \\
\hline GDP & $\begin{array}{l}\text { GDP per capita of the } \\
\text { developing countries } \\
\text { in } 2000\end{array}$ & $\begin{array}{l}\text { The } \\
\text { World } \\
\text { bank }\end{array}$ & $\begin{array}{ll}\text { current US } \\
\text { dollars }\end{array}$ & $\begin{array}{l}\text { Collected } \mathrm{f} \\
\text { each } \\
\text { developing } \\
\text { country } \mathrm{f} \\
\text { year 2000 }\end{array}$ & $\begin{array}{l}\text { Higher GDP level } \\
\text { will result in lower } \\
\text { gender gap in } \\
\text { literacy }\end{array}$ \\
\hline GOV & $\begin{array}{l}\text { government } \\
\text { expenditure } \\
\text { education of the } \\
\text { developing countries } \\
\text { in } 2000\end{array}$ & $\begin{array}{l}\text { The } \\
\text { World } \\
\text { bank }\end{array}$ & $\begin{array}{l}\text { percentage } \\
\text { of GDP }\end{array}$ & $\begin{array}{l}\text { Collected } \mathrm{f} \\
\text { each } \\
\text { developing } \\
\text { country } \mathrm{f} \\
\text { year 2000 }\end{array}$ & $\begin{array}{l}\text { Higher government } \\
\text { expenditure will } \\
\text { result in lower } \\
\text { gender gap in } \\
\text { literacy }\end{array}$ \\
\hline URBAN & $\begin{array}{l}\text { urban population of } \\
\text { the developing } \\
\text { countries in } 2000\end{array}$ & $\begin{array}{l}\text { The } \\
\text { World } \\
\text { bank }\end{array}$ & $\begin{array}{l}\text { percentage } \\
\text { of total } \\
\text { population }\end{array}$ & $\begin{array}{l}\text { Collected } \\
\text { each } \\
\text { developing } \\
\text { country } \\
\text { year } 2000\end{array}$ & $\begin{array}{l}\text { Higher urbanization } \\
\text { level will result in } \\
\text { lower gender gap in } \\
\text { literacy }\end{array}$ \\
\hline PROTESTANT & $\begin{array}{l}\text { Protestant adherents } \\
\text { of the developing } \\
\text { countries in } 2000\end{array}$ & $\begin{array}{l}\text { The } \\
\text { World } \\
\text { Factbook }\end{array}$ & $\begin{array}{l}\text { percentage } \\
\text { of total } \\
\text { population }\end{array}$ & $\begin{array}{l}\text { Collected } \mathrm{f} \\
\text { each } \\
\text { developing } \\
\text { country } \mathrm{f} \\
\text { year 2000 }\end{array}$ & $\begin{array}{l}\text { More protestant will } \\
\text { result in lower } \\
\text { gender gap in } \\
\text { literacy }\end{array}$ \\
\hline CATHOLIC & $\begin{array}{ll}\text { Roman } & \text { Catholic } \\
\text { adherents } & \text { of the } \\
\text { developing } & \text { countries } \\
\text { in } 2000 & \end{array}$ & $\begin{array}{l}\text { The } \\
\text { World } \\
\text { Factbook }\end{array}$ & $\begin{array}{l}\text { percentage } \\
\text { of total } \\
\text { population }\end{array}$ & $\begin{array}{l}\text { Collected } \mathrm{f} \\
\text { each } \\
\text { developing } \\
\text { country } \mathrm{f} \\
\text { year 2000 }\end{array}$ & $\begin{array}{l}\text { More protestant will } \\
\text { result in higher } \\
\text { gender gap in } \\
\text { literacy }\end{array}$ \\
\hline
\end{tabular}




\begin{tabular}{|c|c|c|c|c|c|}
\hline ISLAM & $\begin{array}{l}\text { Islam adherents of the } \\
\text { developing countries } \\
\text { in } 2000\end{array}$ & $\begin{array}{l}\text { The } \\
\text { World } \\
\text { Factbook }\end{array}$ & $\begin{array}{l}\text { percentage } \\
\text { of total } \\
\text { population }\end{array}$ & $\begin{array}{ll}\text { Collected for } \\
\text { each } \\
\text { developing } \\
\text { country for } \\
\text { year 2000 }\end{array}$ & $\begin{array}{l}\text { More protestant will } \\
\text { result in higher } \\
\text { gender gap in } \\
\text { literacy }\end{array}$ \\
\hline OTHERS & $\begin{array}{l}\text { other religions } \\
\text { adherents other than } \\
\text { Protestant, Roman } \\
\text { Catholic, Islam of the } \\
\text { developing countries } \\
\text { in } 2000\end{array}$ & $\begin{array}{l}\text { The } \\
\text { World } \\
\text { Factbook }\end{array}$ & $\begin{array}{l}\text { percentage } \\
\text { of total } \\
\text { population }\end{array}$ & $\begin{array}{ll}\text { Collected for } \\
\text { each } \\
\text { developing } \\
\text { country for } \\
\text { year 2000 }\end{array}$ & $\begin{array}{l}\text { More protestant will } \\
\text { result in higher } \\
\text { gender gap in } \\
\text { literacy }\end{array}$ \\
\hline
\end{tabular}

\section{Copyright Disclaimer}

Copyright for this article is retained by the author(s), with first publication rights granted to the journal.

This is an open-access article distributed under the terms and conditions of the Creative Commons Attribution license (http://creativecommons.org/licenses/by/4.0/). 